\title{
CORACOID STRESS INJURY: A REPORT OF AN UNUSUAL CASE AND REVIEW OF LITERATURE
}

\author{
lqbal A., Botchu R.
}

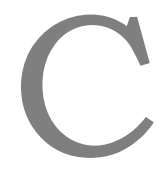

oracoid stress fractures are extremely rare and all reported cases are sports related. We present an unusual case of a coracoid stress injury in a 64-year-old, non-athletic female, who presented with a three-month history of increasing pain on the anterior aspect of her shoulder. MRI and CT revealed a stress fracture of the anterior subcortical aspect of the coracoid process.

Keywords: coracoid, stress, injury.

Corresponding author: Rajesh Botchu, e-mail: drbrajesh@yahoo.com

For citation: Iqbal A., Botchu R. Coracoid stress injury: a report of an unusual case and review of literature. REJR 2020; 10(3):174-178. DOI:10.21569/2222-7415-2020-10-3174-178.

Received: $\quad 13.04 .20 \quad$ Accepted: $\quad 19.08 .20$

\section{СТРЕСС-ПЕРЕАОМ КАЮВОВИАНОГО ОТРОСТКА АОПАТКИ: КАИНИЧЕСКИЙ САУЧАЙ И ОБЗОР АИТЕРАТУРЫ}

\author{
Икбал А., Ботчу Р.
}

тресс-переломы клювовидного отростка мопатки встречаются крайне редко, и все зарегистрированные случаи связаны со спортом. Мы представляем необычный случай стресс-перелома клювовидного отростка цопатки у 64метней женщины, не занимающейся спортом, у которой в течение трех месяцев в анамнезе наблюдалась нарастающая боль в переднем отделе плеча. С помощью МРТ и МСКТ был выявлен стресс-перелом передней субкортикальной части клювовидного отростка мопатки.

КАючевые слова: клювовидный отросток мопатки, стресс-перелом, травма.

Контактный автор: Rajesh Botchu, e-mail: drbrajesh@yahoo.com

Для иитирования: Икбал А., Ботчу Р. Стресс-перелом клювовидного отростка лопатки: клинический случай и обзор литературы. REJR 2020; 10(3):174-178. DOI: $10.21569 / 2222-7415-2020-10-3-174-178$.
Статья получена:
13.04.20
Статья принята:
03.03.20

Department of Musculoskeletal Imaging, Royal Orthopaedic Hospital. Birmingham, UK.
Отделение скелетномышечной визуализации, Королевский ортопедический госпиталь. Бирмингем, Великобритания. 


\section{RUSSIAN ELECTRONIC JOURNAL OF RADIOLOGY}

I

ntroduction.

Scapula fractures constitute approximately $3 \%$ to $5 \%$ of all shoulder related injuries and most commonly arise as a result of direct high energy trauma [1]. Coracoid fractures are extremely rare and account for approximately $2-7 \%$ of all scapula fractures [2]. High energy mechanisms such as motor vehicle accidents or high impact sports injuries account for the majority of these. Coracoid stress fractures form a small subgroup of these with only 9 cases reported in the literature all of whom occurred in repetitive sport related injuries. We present an unusual case of a coracoid stress injury in a non-athletic individual. graphs were unremarkable and a subsequent CT shoulder demonstrated mild sclerosis of the coracoid (Fig. 2).

Following a period of prolonged rest the patient's symptoms completely resolved and a follow up CT 3 months later revealed no evidence of a fracture. The patient was subsequently discharged.

To date, only nine cases of coracoid stress fractures have been reported in the literature between 1971-2019. All cases were related to sporting activities with cricket being the commonest sport resulting in coracoid stress fracture in four cases. The first reported case of a stress fracture of the coracoid process was described by Benton

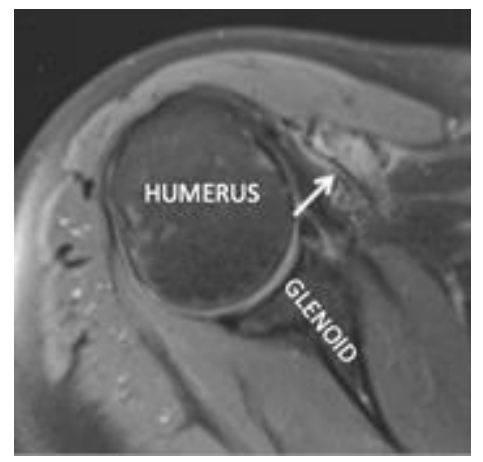

Fig. 1 a (Pис. 1 a)

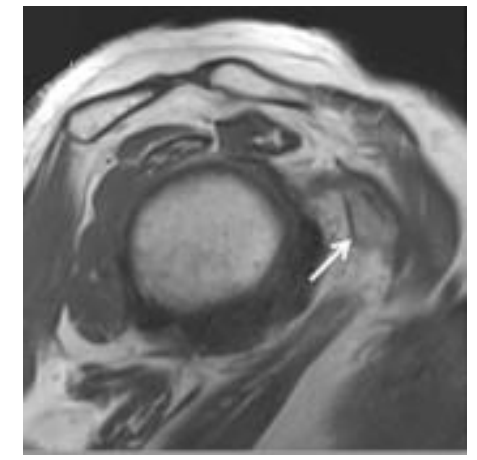

Fig. 1 b (Рис. 1 б)

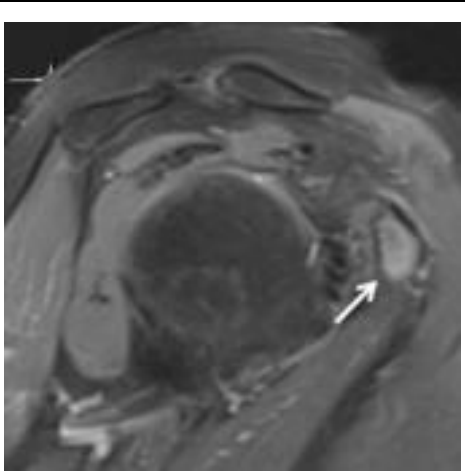

Fig. 1 с (Рис. 1 в)

Fig. 1. MRI.

a - PDFS axial, b - PD sag, c - PDFS sag, demonstrates osseous edema with subcortical stress fracture of coracoid (arrow).

Pис. 1. MPT.

a - аксиальная реконструкция, PDFS, б - сагиттальная реконструкция PD, в - сагиттальная реконструкция, PDFS. Определяется отек костной ткани со стресс-переломом кАювовидного отростка цопатки в субкортикальном отделе (стрелка).

\section{Case.}

This is a case of a 64-year-old female who presented with a three-month history of increasing pain on the anterior aspect of her shoulder, which had recently worsened. She recently rigorously renovated her house after flooding which coincided with onset of her symptoms. Nine years prior, she had a rotator cuff repair, biceps tenotomy and subacromial decompression with acromioclavicular (AC) joint excision of the right shoulder. Clinical examination revealed good global range of movement but with pain radiating down the middle of her arm.

Plain radiographs were unremarkable. MRI revealed focal oedema involving the coracoid process with surrounding oedema on fluid sensitive sequences. Sagittal T1 sequence revealed an undisplaced low signal subcortical fracture line extending parallel to the anterior cortex of the coracoid process in keeping with a fredericson $4 \mathrm{~b}$ fracture (Fig. 1).

The rotator cuff repair was intact. Radio- et al 1971 (i) in a 19 year old male tennis player who suffered a 4 year history of progressive anterior shoulder pain directly related to tennis playing. Of the remaining cases, two were related to trapshooting, one was each related to golf and water polo respectively. The age range was $14-50$ years with a mean age of 26 years (two studies did not include age). Seven cases involved males and two involved females. Seven cases of coracoid stress fractures involved the base of the coracoid process of which six were conservatively managed and one patient who was a professional international cricketer underwent percutaneous screw fixation following failed conservative therapy. Two patients had avulsion fractures of the distal tip of the coracoid and both were surgically managed. The mean time of return to sporting activity was 4.7 months (range 2.5-12 months).

\section{Discussion.}

Stress fractures of the coracoid process are extremely rare with only 9 cases reported in the literature all of whom occurred as a result of re- 


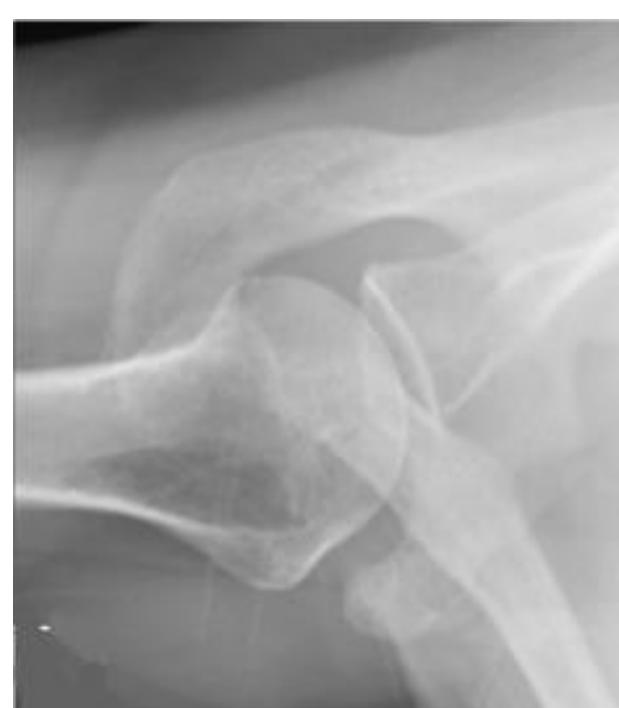

Fig. 2 a (Рис. 2 a)

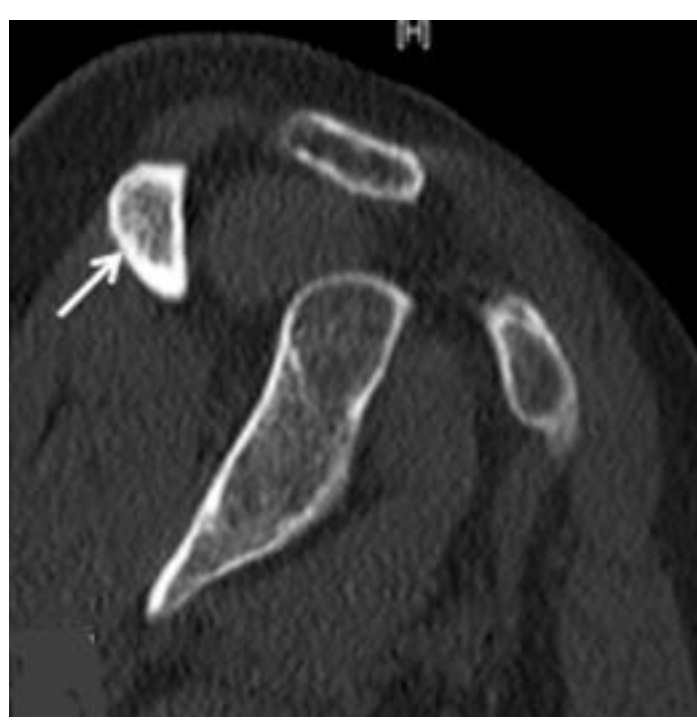

Fig. 2 b (Рис. 2 б)

Fig. 2. a - Axial radiograph is unremarkable, b - sagittal reconstruction of $\mathrm{CT}$, showing mild sclerosis of coracoid process (arrow).

Рис. 2. а - Рентгенограмма, аксиальная проекция, без особенностей, б - МСКТ, сагиттальная реконструкция, показывающая умеренные склеротические изменения кАювовиАного отростка ^опатки (стрелка).

petitive sport related injuries. The majority of these were successfully managed conservatively with rest and activity modification, however, 3 patients underwent surgery, all of whom returned to sporting activity.

Anatomically, the coracoid process is a hook-like structure, which arises from the lateral edge of the anterior-superior scapula just medial to the glenoid (Fig. 3).

It is an important to stabilizer the shoulder joint along with the acromion. It serves as the attachment site of the coracobrachialis, pectoralis minor and short head of biceps tendons as well as the coracohumeral, coracoclavicular and coracoacromial ligaments.

A number of classifications for coracoid fractures exist, of which the Ogawas classification is the simplest and most commonly used [12]. It divides fractures into two types according to their location in relation to the coracoclavicular ligament (CCL). Type I fractures are proximal to the CCL and occur with a variety of associated shoulder injuries such as acromioclavicular dissociation, scapula spine fracture, acromion and clavicle fractures. Isolated fractures of the base of the coracoid may also occur. Type II fractures are rare and occur distal to the CCL and are usually related to muscle attachments.

Stress injuries are a spectrum of pathologies ranging from periostitis secondary to inflammation of the periosteum to a complete cortical break. Pathophysiologically, in healthy bone physical activity results in microtrauma to bone which is repaired by osteoblastic activity. However, when the recovery period is insufficient as in repetitive activity, the rate of osteoclastic activity exceeds new bone formation leading to bone weakness and stress reaction over a period of time. The Fredericson classification system is commonly used to stage stress injuries on MRI. Grade I represents periosteal oedema. Grade II represents bone marrow oedema on T2 weighted images only whilst Grade III represents marrow oedema on T1 and T2 weighted sequences. Grade $4 a$ represents discrete intracorical signs and Grade $4 b$ represents linear intracortical fracture lines [13].

Stress injuries are common in athletes and result from repetitive submaximal loading on bone over time. They are most commonly involve the lower limbs in running and jumping. Upper limb stress injuries are rare and most commonly involve the ulna. Stress injuries often occur as a change in routine such as intensity and training surface and are therefore common in military recruits and runners [14].

Our case was an unusual presentation of a coracoid stress fracture unrelated to sporting activity, which has not been previously been described in the literature. Our patient in this case was a 64 year old female who developed anterior shoulder pain following intense renovation of her property over a period of months after flooding. MRI and CT revealed a stress fracture of the anterior subcortical aspect of the coracoid process. Whilst there is no similar case in the literature, there is a case report of a 50 year old female de- 


\begin{tabular}{|c|c|c|c|c|c|c|c|}
\hline \multicolumn{8}{|c|}{ Review of the literature. } \\
\hline Study & Journal (year) & Age & Sex & Activity & $\begin{array}{l}\text { Fracture } \\
\text { Pattern }\end{array}$ & Treatment & $\begin{array}{l}\text { Return } \\
\text { to sport } \\
\text { (months) }\end{array}$ \\
\hline $\begin{array}{l}\text { Benton } \\
\text { and nel- } \\
\text { son et al } \\
\text { (3) }\end{array}$ & JBJS 1971 & 19 & M & Tennis & $\begin{array}{l}\text { avulsion distal } \\
\text { half }\end{array}$ & $\begin{array}{l}\text { fracture excision, reat- } \\
\text { tachment of conjoined } \\
\text { tendon }\end{array}$ & 2.5 \\
\hline $\begin{array}{l}\text { Sandroc } \\
\mathrm{k} \text { et al } \\
(4)\end{array}$ & Radiology 1975 & NR & $\mathrm{F}$ & $\begin{array}{l}\text { Trapshoo } \\
\text { ting }\end{array}$ & $\begin{array}{l}\text { middle of } \\
\text { coracoid }\end{array}$ & conservative & 3 \\
\hline $\begin{array}{l}\text { Boyer et } \\
\text { al (5) }\end{array}$ & JBJS 1975 & 27 & M & $\begin{array}{l}\text { Trapshoo } \\
\text { ting }\end{array}$ & $\begin{array}{l}\text { transverse } \\
\text { fracture of } \\
\text { base }\end{array}$ & conservative & 2.5 \\
\hline $\begin{array}{l}\text { Ashbury } \\
\text { and ten- } \\
\text { ant et al } \\
\text { (6) }\end{array}$ & Injury 2005 & 27 & M & Cricket & $\begin{array}{l}\text { base of } \\
\text { coracoid }\end{array}$ & conservative & 3 \\
\hline $\begin{array}{l}\text { Chamma } \\
\text { et al ( } 7)\end{array}$ & $\begin{array}{l}\text { American journal } \\
\text { of sports medicine } \\
2010\end{array}$ & 27 & M & Cricket & $\begin{array}{l}\text { Base of cora- } \\
\text { coid into gle- } \\
\text { noid }\end{array}$ & conservative & 6 \\
\hline $\begin{array}{l}\text { Archik } \\
\text { et al (8) }\end{array}$ & $\begin{array}{l}\text { Journal of ortho- } \\
\text { pedic case reports } \\
2016\end{array}$ & 15 & M & Cricket & $\begin{array}{l}\text { Avulsion } \\
\text { distal tip }\end{array}$ & ORIF & 2.5 \\
\hline $\begin{array}{l}\text { Lee et al } \\
(9)\end{array}$ & $\begin{array}{l}\text { Knee Surg Sports } \\
\text { Traumatol Ar- } \\
\text { throsc } 2018\end{array}$ & 50 & $\mathrm{~F}$ & Golf & $\begin{array}{l}\text { Base of } \\
\text { coracoid }\end{array}$ & conservative & 12 \\
\hline $\begin{array}{l}\text { Thompro } \\
\mathrm{n} \text { et al } \\
(10)\end{array}$ & $\begin{array}{l}\text { Skeletal } \\
\text { Radiology } 2019\end{array}$ & NR & M & Cricket & $\begin{array}{l}\text { Base of } \\
\text { coracoid }\end{array}$ & Percutaneous screw & 11 \\
\hline $\begin{array}{l}\text { Wollstei } \\
\mathrm{n} \text { et al } \\
(11)\end{array}$ & $\begin{array}{l}\text { Der Unfallchirurg } \\
2018\end{array}$ & 14 & M & $\begin{array}{l}\text { Waterpol } \\
\text { o }\end{array}$ & $\begin{array}{l}\text { Base of } \\
\text { coracoid }\end{array}$ & conservative & 3.5 \\
\hline
\end{tabular}

veloping a coracoid stress fracture after 3 months of learning to play golf at a driving range [9]. Lee et al proposed a number of potential theories which may have accounted for their case of stress fracture such as the repetitive forces on the coracoid during the different phases of the golf swing and the possibility of osteoporosis resulting in an insufficiency fracture. There is evidence that bone mineral density of the coracoid process decreases with age with suggestion of a predisposition to fracture from lower energy mechanisms [15]. Alt- hough the patient in our study was postmenopausal, there were no other predisposing factors that pointed towards an insufficiency fracture. There was no history of chronic disease, endocrine disorder or steroid use and the patient haematological bone profile was within normal limits. Although subjective, the coracoid process on plain radiographs and CT did not appear osteopenia. As a result, we conclude that this was indeed a stress fracture of the coracoid rather than an insufficiency fracture due to osteoporosis. It is 


\section{RUSSIAN ELECTRONIC JOURNAL OF RADIOLOGY}

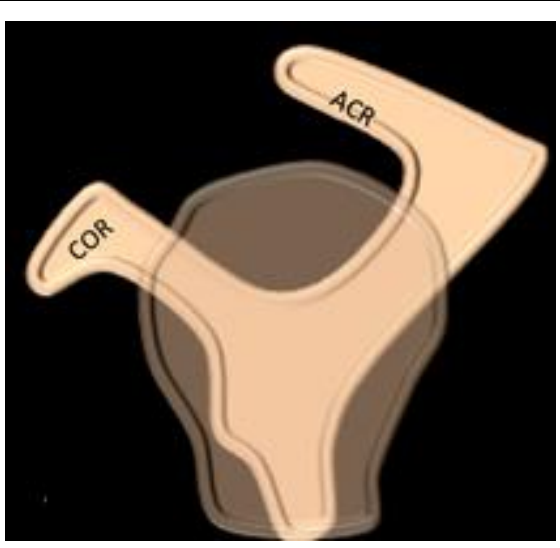

Fig. 3 a (Рис. 3 a)

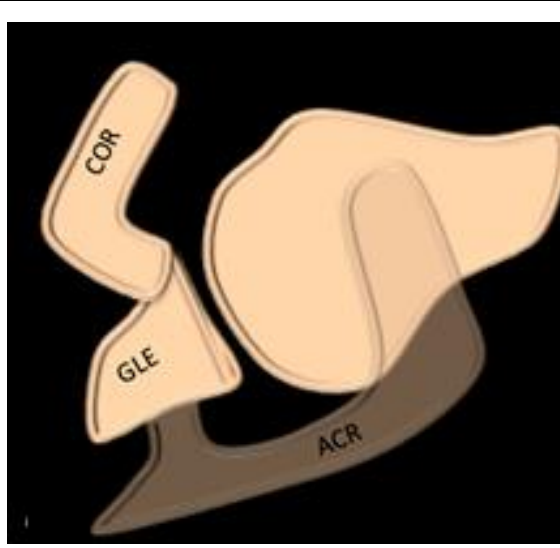

Fig. 3 b (Рис. 3 б)

\section{Fig. 3. Scheme.}

a - sagittal, b - axial. Animation of shoulder showing coracoid (COR) and acromion (ACR). GLE (glenoid).

\section{Рис. 3. Схема.}

а - сагиттальный срез, б - аксиальный срез. Схематическое изображение плечевого сустава, клювовидного отростка мопатки (COR) и акромиона (ACR). GLE (гленоид).

highly likely that the activities related to rigorous renovation over a short period of time, which the patient was not accustomed to result in the stress fracture. Furthermore, after a period of rest there was complete resolution of symptoms with no evidence of a fracture on follow up CT.

\section{Conclusion.}

Coracoid stress fractures are rare and have

\section{References:}

1. Hardegger F.H., Simpson L.A., Weber B.G. The operative treatment of scapular fractures. J Bone Joint Surg Br. 1984; 66: 725-31.

2. Ada J.R., Miller M.E. Scapular fractures: analysis of 113 cases. Clin Orthop. 1991; 269: 174-80.

3. Benton J., Nelson C. Avulsion of the coracoid process in an athlete: report of a case. J Bone Joint Surg Am. 1971; 53 (2): 356-358.

4. Sandrock A.R. Another sports fatigue fracture: stress fracture of the coracoid process of the scapula. Radiology. 1975; 117 (2): 274.

5. Boyer D.W. Jr. Trapshooter's shoulder: stress fracture of the coracoid process. Case report. J Bone Joint Surg Am. 1975; 57 (6): 862 .

6. Asbury S., Tennent T.D. Avulsion fracture of the coracoid process: a case report. Injury. 2005; 36 (4): 567-568.

7. Chammaa R., Miller D., Datta P., et al. Coracoid stress fracture with late instability. Am J Sports Med. 2010; 38 (11): 2328 2330.

8. Archik S., Nanda S.N., Tripathi S., et al. An isolated displaced fracture of the coracoid process treated with open reduction and internal fixation - a case report and review of literature. J Orthop Case Rep. 2016; 6 (1): 37-39.

9. Lee J.H., Kim J.R., Wang S.I. An unusual mechanism of cora- previously only been in sport related activities. They most commonly involve the base of the coracoid process with the majority conservatively managed. We have described an unusual pattern of coracoid stress injury in non-athletic female that was conservatively managed with complete resolution of symptoms.

coid fracture in a beginner golfer. Knee Surg Sports Traumatol Arthrosc. 2018; 26 (1): 76-78.

10. Thompson G., Van Den Heever A. Coracoid stress fracture in an elite fast bowler: description of a technique for CT-guided percutaneous screw fixation of coracoid fractures. Skeletal Radiology. 2019; 48 (10): 1611-1616.

11. Wollstein J., Tegtbur U., Meller R., Hanke A.A., Berndt T., Krettek C., Weber-Spickschen T.S. Isolated fracture of the coracoid process in a 14-year-old national water polo player. Case example. Unfallchirurg. 2019; 122: 79-82.

12. Ogoawa K., Yoshida A., Takahashi M., Ui M. Fractures of the coracoid process. J Bone Joint Surg Br. 1997; 79 (1): 17-9.

13. Fredericson M., Bergman A.G., Hoffman K.L., Dillingham M.S. Tibial stress reaction in runners: correlation of clinical symptoms and scintigraphy with a new magnetic resonance imaging grading system. Am J Sports Med. 1995; 23: 472-481

14. Kiel J., Kaiser K. Stress Reaction and Fractures. [Updated 2019 Jun 4]. In: Stat Pearls [Internet]. Treasure Island (FL): Stat Pearls Publishing; 2019 Jan-. Available from: https://www.ncbi.nlm.nih.gov/books/NBK507835/

15. Beranger J.S., Maqdes A., Pujol N., Desmoineaux P., Beau ls. $P$. Bone mineral density of the coracoid process decreases with age. Knee Surg Sports Traumatol Arthrosc. 2016; 24 (2): 502-506. 